\title{
Pengembangan Panduan Konseling Psikoreligius Untuk Remaja Korban Kekerasan
}

\author{
Yulia Sholichatun \\ Psikologi Klinis, Universitas Islam Negeri Maulana Malik Ibrahim Malang, Indonesia \\ Email:sholihah.y@gmail.com
}

Miftahus Surur

Bimbingan dan Konseling, Universitas Islam Negeri Maulana Malik Ibrahim Malang, Indonesia Email:surur@uin-malang.ac.id

(Diterima: 03-Mei-2018; direvisi: 19-Juli-2018; dipublikasikan: 29-Desember-2018)

\begin{abstract}
The purpose of this study was to develop a guide to psycho-religious counseling and examine whether psychiatric counseling guidelines can help overcome the effects of violent trauma on adolescents. The method used is the research and development ( $R \& D$ ) model. The procedure of development research includes: 1) the preparation stage, 2) the implementation stage, namely drafting the product, and 3) product testing or product validation and preparation of the final product. This product is tested by a team of experts consisting of a religious expert and a psychologist and validated by experts. In the implementation phase an assessment of the symptoms of post-traumatic stress experienced by teenage respondents who were victims of violence was conducted before counseling and after counseling. Research data were analyzed quantitatively descriptive and qualitative. The results show that counseling guidelines have been developed validally both in terms of usability, accuracy, suitability and ease of guidance in the implementation of counseling for adolescents who are victims of violence. The results of the qualitative analysis of three teenage respondents who were victims of violence at the time of implementation of the guidelines also showed a decrease in symptoms of post-traumatic stress and an increase in religious behavior after attending psycho-religious counseling.
\end{abstract}

Keywords: Psychoreligious Counseling, Youth, Victims of Violence

Abstrak - Tujuan penelitian ini adalah untuk menyusun panduan konseling psikoreligius dan menguji apakah panduan konseling psikoreligius dapat membantu mengatasi efek trauma kekerasan pada remaja. Metode yang digunakan adalah model research and development $(R$ \& D). Prosedur penelitian pengembangan ini meliputi: 1) tahap persiapan, 2) tahap pelaksanaan, yaitu penyusunan draf produk, dan 3) Uji coba produk atau validasi produk dan penyusunan produk akhir. Produk ini diuji oleh tim ahli yang terdiri dari seorang ahli keagamaan dan seorang ahli psikologi serta divalidasi oleh para ahli. Pada fase implementasi dilakukan asesmen terhadap gejala stress pasca trauma yang dialami oleh para responden remaja korban kekerasan sebelum diberikan konseling dan setelah dilakukan konseling. Data penelitian dianalisa secara kuantitatif deskriptif dan kualitatif. Hasil menunjukkan bahwa panduan konseling telah dikembangkan secara valid baik dari sisi kegunaan, ketepatan, kesesuaian dan kemudahan panduan di dalam pelaksanaan konseling bagi remaja korban kekerasan. Hasil analisa kualitatif terhadap tiga responden remaja korban kekerasan pada saat implementasi panduan juga menunjukkan adanya penurunan gejala-gejala stres pascatrauma dan peningkatan perilaku religiusnya setelah mengikuti konseling psikoreligius.

Kata kunci: Konseling Psikoreligius, Remaja, Korban Kekerasan

Copyright () 2018 Universitas Negeri Makassar. This is an open access article under the CC BY-NC-ND license (http://creativecommons.org/licenses/by-nc-nd/4.0/). 


\section{PENDAHULUAN}

Kasus kekerasan terhadap anak dan remaja merupakan fenomena yang makin marak terjadi di Indonesia. Menurut data dari Komisi Perlindungan Anak Indonesia (KPAI), tren kasus kekerasan pada anak di Indonesia menunjukkan peningkatan setiap tahunnya. KPAI juga mencatat setidaknya 1000 kasus kekerasan pada anak dan remaja telah terjadi di tahun 2016, 136 kasus diantaranya dilakukan melalui media sosial (kpai, 2017).

Data statistik terkait korban kekerasan di atas sejalan dengan hasil penelitian Sholichatun (2015) tentang karakteristik korban, pelaku dan bentuk kekerasan pada anak di Kabupaten Malang antara tahun 2012-2015. Hasil penelitian tersebut menunjukkan jumlah keseluruhan kasus yang didampingi oleh P2TP2A Kabupaten Malang sebanyak 98 kasus. Namun dari total kasus di atas yang berjumlah 98, hanya ada 14 kasus yang menimpa perempuan sehingga total kasus pada anak sejumlah 70 kasus dengan kasus terbanyak kekerasan seksual yakni sebanyak 38 kasus. Berdasarkan kategori usia, dari 70 kasus tersebut usia para korban yang termasuk kategori anak-anak sejumlah 19 orang dan korban yang berusia remaja sebanyak 51 orang. Mayoritas korban dengan demikian adalah para remaja.

Tindak kekerasan yang dilakukan pada anak dapat memberikan banyak dampak psikologis. MacMillan (2001) me-review sejumlah penelitian tentang pengaruh kekerasan terhadap kondisi psikologis anak. Anak dan remaja yang mengalami kekerasan seksual dan fisik menunjukkan tingginya simtom kecemasan, depresi, dan sindrom pasca trauma (PTSD). Mereka juga lebih mudah untuk merasa bersedih serta mengalami distress. Kondisi ini selanjutnya berpengaruh pada kesehatan mental dan kesejahteraan psikologis mereka dalam jangka panjang. Hasil penelitian Johnson, et al (2002) juga menguatkan hal tersebut, bahwa anak-anak korban kekerasan berpotensi untuk memiliki problem emosi dan perilaku. Selain problemproblem emosi dan perilaku, MacMillan (2001) dalam review-nya juga mengutip sejumlah hasil penelitian tentang kecenderungan anak korban kekerasan untuk terlibat dalam problem perilaku eksternal seperti agresivitas dan bentuk-bentuk kenakalan remaja lainnya termasuk penyalahgunaan obat. Hasil tersebut juga dikuatkan oleh penelitian penelitian Appleyard, Yang \& Runyan (2010).
Hasil pemeriksaan psikologis yang dilakukan peneliti terhadap sejumlah anak korban kekerasan sejalan dengan hasil-hasil penelitian di atas. Anak dan remaja yang mengalami kekerasan menunjukkan banyak simtom kecemasan, trauma, dan bahkan depresi (dokumentasi Unit Layanan Psikologi Fakultas Psikologi Universitas Islam Negeri Maulana Malik Ibrahim Malang terkait hasil pemeriksaan psikologis korban kekerasan periode tahun 20152017). Temuan penelitian yang dilakukan oleh Puspitawati, Djamaludin dan Nursanti (2011) di Kabupaten Bogor juga membuktikan efek kekerasan dapat muncul dalam rentang ringan hingga berat. Anak-anak korban kekerasan yang memiliki efek psikologis berat menunjukkan perilaku penggunaan narkoba serta tindakan agresif, yang merupakan bentuk-bentuk problem perilaku eksternal, dan tindakan bunuh diri karena keputusasaan merupakan efek terberat yang termasuk dalam problem perilaku internal.

Bertolak dari banyaknya efek psikologis yang akan dialami oleh anak dan remaja korban kekerasan tersebut, maka langkah pemberian bantuan menjadi hal yang penting untuk dilakukan. Friedrich (2002) menyatakan terapi untuk anak yang mengalami pelecehan seksual sebaiknya memfasilitasi pemrosesan ketegangan dan perasaan-perasaan yang bercampuraduk yang muncul karena tindak pelecehan. Terapi tersebut hendaknya memberikan perubahan positif terhadap evaluasi diri secara kognitif yang mengalami pelemahan.

Sejalan dengan hal tersebut, Carr (2006) menyatakan pendekatan terapi secara individual dapat dilakukan untuk membantu melepaskan perasaan-perasaan negatif, memproses memori terkait trauma, memeriksa persepsi diri serta mempelajari ketrampilan asertif. Media yang digunakan menurut Carr dapat berupa permainan-permainan, menggambar maupun media lain yang dapat mengeluarkan keyakinan dan perasaan tentang trauma seksual mereka. Mengacu pada pendapat Carr (2006) tentang bentuk intervensi bagi anak korban kekerasan dapat disimpulkan bahwa sasaran terapinya adalah membantu mengeluarkan keyakinan dan perasaan korban terhadap pengalaman kekerasan yang mereka alami serta memfasilitasi pemrosesan pikiran dan perasaan tentang pengalaman tersebut. Setelah proses pelesapan keyakinan (negatif) dan perasaan (negatif) dilakukan maka langkah berikutnya adalah membantu memberikan perubahan positif 
terhadap evaluasi diri yang mengalami pelemahan akibat masalah tersebut.

Proses pelepasan pikiran dan perasaan negatif terhadap pengalaman kekerasan dan proses perubahan positif untuk memunculkan harga diri positif setelah mengelami pelemahan akibat kekerasan dapat dilakukan melalui pendekatan psikoreligius spiritual. Meichenbaum seorang ahli terapi kognitif menegaskan pentingnya spiritualitas dalam proses penyembuhan termasuk untuk kasus trauma (melissainstitude, 2017). Kolaborasi spiritual dalam konseling dan psikoterapi menjadi hal yang penting terutama setelah banyaknya penelitian yang membuktikan peran keyakinan dan perilaku spiritual dalam kesehatan mental dan pengaruhnya dalam proses psikoterapi (Daniels \& Fitzpatrick, 2013; Plumb, 2011).

Carr (2006) yang menyatakan pentingnya upaya mengeluarkan keyakinan dan perasaan korban terhadap pengalaman kekerasan yang dialami, maka menarasikan pengalaman dapat menjadi cara awal untuk membantu korban kekerasan yang umumnya juga merupakan pengalaman traumatik. Menarasikan pengalaman traumatik dapat dilakukan melalui aktivitas religi dan spiritual sebagai cara untuk mendorong ekspresi emosi, kontrol emosi dan kenyamanan emosi antara lain melalui doa, meditasi dan mindfulness, serta penerimaan dan memaafkan (Emmons, 2005; Watts, 2007)

Pertanyaan yang muncul selanjutnya adalah bagaimana proses pemberian bantuan kepada remaja korban kekerasan tersebut dapat diberikan secara luas oleh anggota masyarakat mengingat tingginya jumlah korban kekerasan dari kalangan anak dan remaja. Apabila pemberian bantuan hanya mengandalkan profesional helper maka akan banyak korban yang tidak memperoleh pertolongan. Sementara itu memberikan bantuan tanpa kejelasan prosedur yang telah teruji efektif dapat memberikan efek yang tidak dapat dievaluasi keberhasilannya, yang dapat berdampak pada ketidakjelasan hasil bantuan tersebut bagi para korban/klien yang membutuhkan.

Hasil penelitian Sholichatun (2015) menunjukkan keberadaan shelter di unit pelayanan dan perlindungan anak (P2TP2A) bagi para korban belum dapat memberikan layanan konseling secara optimal terhadap para korban dikarenakan beberapa kendala. Selain jumlah konselor terlatih yang masih kurang, para korban juga seringkali masih memerlukan pendampingan lebih lanjut selepas keluar dari shelter P2TP2A. Namun proses pendampingan selanjutnya tidak bisa dilakukan karena korban sudah kembali ke rumah mereka. Jauhnya jarak rumah para korban dari shelter P2TP2A menjadi kendala untuk melanjutkan pendampingan. Keberadaan konselor di tingkat kecamatan atau di puskesmas belum memadai sehingga para korban tidak dapat mengakses bantuan psikologis bagi permasalahan mereka. Para tenaga medis di puskesmas disamping jumlahnya terbatas, mayoritas mereka juga belum memiliki pengetahuan bagaimana mendampingi para korban kekerasan.

Berdasarkan pada permasalahan tersebut maka penelitian ini dilakukan untuk mengembangkan panduan konseling untuk membantu remaja korban kekerasan dan menguji apakah panduan konseling tersebut dapat diimplementasikan untuk para remaja korban kekerasan.

Modul yang ditulis dalam penelitian ini merupakan adaptasi dari modul untuk penanganan trauma untuk remaja yang disusun oleh Cohen, Mannarino \& Deblinger (2006). Namun penelitian ini tidak murni menggunakan pendekatan Cognitive Behavior Therapy sebagaimana yang dipakai oleh Cohen et al. Penelitian ini lebih mendasarkan pijakan pada sejumlah teori serta pemikiran-pemikiran dan perilaku religius. Pemilihan media atau aktivitas dalam modul penelitian ini mengacu pada Geldard, Geldard \& Foo (2016) bahwa untuk remaja maka penggunaan buku, buku kerja dan menggambar sangat sesuai. Bagi remaja akhir, media konseling menggambar juga masih sangat sesuai, namun kertas kerja dan buku atau cerita kurang sesuai. Berdasarkan hal tersebut maka modul ini menggunakan media buku kerja yang didalamnya terdapat aktivitas menggambar, menulis dan bercerita yang masih cukup relevan bagi remaja.

Isi dari modul secara umum mencakup dua hal utama yang berpijak pada pendapat Carr (2006) tentang bentuk intervensi bagi anak remaja korban kekerasan yaitu membantu mengeluarkan keyakinan dan perasaan korban terhadap pengalaman kekerasan yang mereka alami serta memfasilitasi pemrosesan pikiran dan perasaan tentang pengalaman tersebut. Langkah berikutnya adalah membantu memberikan perubahan positif terhadap evaluasi diri yang mengalami pelemahan akibat masalah tersebut. Membangun rapport dilakukan baik secara informal sebelum sesi dilakukan maupun secara formal. Rapport yang bersifat formal tercantum 
dalam Book A tentang orientasi konseling. Orientasi konseling juga telah memuat asesmen khususnya religious.

Penyusunan asesmen gejala PTSD mengacu pada Durrand \& Barlow (2006) dalam bentuk laporan diri. Asesmen religious spiritual untuk mengetahui bagaimana kehidupan religious/spiritual klien yang dimungkinkan akan diperoleh data berupa sumber-sumber kekuatan klien dalam hal keagamaan. Sejalan dengan Richard \& Bergin (2006), asesmen religious diperlukan dalam praktek klinis untuk menemukan sumber-sumber kekuatan klien secara spiritual religious yang dapat digunakan untuk membantu mereka dalam mengatasi permasalahan atau menyembuhkan diri klien. Asesmen religious ini disusun dengan mengacu pada Richard \& Bergin (2006) dan Meichenbaum (tanpa tahun).

Selanjutnya tentang penyusunan Book B yang berisi Psikoedukasi Trauma dan Stress Pasca Trauma mengacu pada penjelasan Carr (2006) bahwa karena banyaknya dampak trauma yang akan berpengaruh pada korban dalam jangka waktu lama maka korban perlu mengerti keadaan apa yang sedang dialaminya. Tujuannya tidak hanya memahami apa yang telah dan sedang terjadi pada dirinya tetapi juga mampu melakukan cara-cara untuk menjaga kestabilan pikiran dan emosi mereka di waktu selanjutnya.

Selain itu Book B memuat tentang psikoedukasi lain terkait upaya untuk menanggulangi pikiran dan perasaan mengganggu yang seringkali dialami oleh para korban kekerasan dengan tehnik stabilisasi. Dasar teori untuk tehnik stabilisasi mengacu pada Shapiro (2012). Memori masa lalu tentang kejadian traumatic disimpan begitu saja di dalam otak dalam cara yang masih mengandung emosiemosi, sensasi-sensasi psikis maupun keyakinankeyakinan sebagaimana yang telah dialami di masa lalu. Kondisi inilah yang menurut Shapiro dialami oleh mereka yang mengalami gejalagejala PTSD. Selanjutnya ia menawarkan sebuah cara untuk menjaga keseimbangan diri yang dapat dilakukan ketika memori-memori tak terproses itu tiba-tiba muncul menggangu pikiran dan emosi seseorang yang disebut dengan tehnik stabilisasi.

Sejumlah tehnik stabilisasi dikenalkan oleh Shapiro namun dalam modul penelitian ini tiga tehnik yaitu pernafasan mendalam, inner safe place dan grounding. Tehnik pernafasan menurut Shapiro lebih menekankan pada pemusatan, tehnik grounding ditujukan untuk memunculkan rasa aman pada "saat ini" sedangkan inner safe place berfungsi memunculkan imaginasi tentang tempat aman di dalam diri sendiri.

Tehnik pernafasan mendalam dan grounding dalam modul ini dipadukan dengan strategi religious. Hal ini didasarkan pada hasil penelitian bertahun-tahun yang dilakukan oleh Herbert Benson yang menemukan bahwa prayer maupun spiritual words dapat digunakan sebagai salah satu tehnik relaksasi (http.psychologytoday). Demikian juga untuk tehnik grounding, peneliti mengintegrasikan dengan ajaran agama yakni dzikr. Menurut Subandi (2012) penggunaan dzikr dengan berbagai lafadz dapat diserupakan dengan meditasi yang memiliki efek menenangkan. Penggunaan dzikr (mengingat Allah) misalnya mengulang-ulang bacaan laa ilaaha illa allaah atau yaa rahmaan yaa rahiim dapat memiliki efek meditatif. Dalam kelompok Sufi meditasi dzikr dilakukan dengan disertai gerakan-gerakan tubuh tertentu.

Isi modul B selanjutnya adalah memberikan pemahaman kepada klien tentang apa itu pikiran dan perasaan serta bagaimana pikiran, perasaan dan tindakan saling terkait satu sama lain. Sebagaimana yang diungkapkan oleh Cohen et al (2006) pemahaman tentang regulasi afek untuk menanggulangi emosi yang muncul sebagai akibat peristiwa trauma. Sejalan dengan Cohen et al, Shapiro (2012) menyatakan pentingnya menguasai cara-cara menstabilkan emosi pada saat jejak-jejak peristiwa masa lalu terlintas kembali di dalam pikiran seseorang.

Berikutnya adalah pijakan teoritik untuk Book $\mathrm{C}$ yang berisi mengatasi trauma. Bagian ini menggunakan tehnik menulis cerita terkait pengalaman traumatic responden/klien yang didasarkan pada penelitian Pennebaker tentang manfaat menulis ekpresif terhadap pengalaman traumatik (1997) dan Chen (2005) tentang pengaruh menulis terhadap simtom PTSD. Penelitian Chen (2005) menguatkan temuan Pennebaker tentang manfaat menulis pengalaman traumatik bagi orang dengan gejala PTSD. Namun dalam penelitiannya, Chen memberikan bentuk intervensi menulis yang berbeda. Rekomendasi hasil penelitian Chen ini adalah perlunya mengintegrasikan religi/spiritual dalam intervensi trauma khususnya pada trauma yang parah. Bertolak dari hasil penelitian Pennebaker dan Chen tersebut maka dalam penelitian ini, peneliti menggunakan tehnik menulis dengan integrasi religious/spiritual sebagai intervensi 
trauma. Bentuk yang dipakai dalam penelitian ini berupa making meaning atau mencari hikmah dari pengalaman traumatic dan menulis doa. Penggunaan doa dalam intervensi trauma ini juga sejalan dengan Meichenbaum (tanpa tahun) dan Richard \& Bergin (2005).

Bagian terakhir dari modul adalah harapan dan masa depan. Bagian Book D ini merupakan target kedua dari sasaran intervensi trauma sebagaimana yang diungkapkan oleh Carr yaitu memberikan perubahan positif terhadap evaluasi diri yang mengalami pelemahan akibat masalah tersebut.

\section{METODE}

Penelitian ini menggunakan model penelitian dan pengembangan atau di sebut juga dengan research and development $(\mathrm{R} \& \mathrm{D})$. Prosedur penelitian pengembangan ini adalah 1) tahap persiapan, 2) tahap pelaksanaan, yaitu penyusunan draf produk, dan 3) Uji coba produk atau validasi produk dan penyusunan produk akhir.

Subjek penelitian yang dalam hal ini adalah pengembangan panduan konseling psikoreligius ini terdiri dari 3 komponen :

1. Ahli

Subjek ahli terdiri dari dua orang pakar (expert judgment), yaitu : (1) psikolog, (2) pakar agama Islam. Pada penelitian ini kualifikasi pakar ahli yang akan me-review dan dipilih untuk menguji kelayakan panduan, Dosen pakar psikologi yang dipilih pada penelitian ini adalah dosen psikologi yang bergelar doktor dari Universitas Negeri Malang dan dosen pakar Agama Islam yang bergelar Doktor dari Institute Agama Islam Negeri (IAIN) Surakarta.

\section{Pengguna Panduan}

Subjek ujicoba pengguna panduan ini dalam penelitian ini adalah psikolog yaitu peneliti dan ahli psikologi yang mereview panduan serta 2 observer dosen Fakultas Psikologi UIN Maulana Malik Ibrahim Malang yang akan menilai proses uji coba penggunaan panduan.

3. Subjek Sasaran

Subjek sasaran pengguna produk panduan ini adalah tiga remaja korban kekerasan yang bersedia menjadi responden penelitian ini dan masih memiliki trauma yang dalam kategori tinggi.

Adapun teknik pengumpulan data yang digunakan dalam penelitian ini adalah : (a) Observasi : Observer dalam penelitian ini terdiri dari 2 dosen Fakultas Psikologi Universitas Islam Negeri Maulana Malik Ibrahim Malang yang telah memiliki pengalaman dan pemahaman dalam keilmuan psikologi. Observer diberikan jabaran variabel yang dijadikan sebagai dasar bahan penilaian panduan pada saat pelaksanaan uji coba di lapangan; (b) Wawancara : dibutuhkan untuk menggali data awal dan informasi mengenai penanganan korban kekerasan anak dan remaja sebelum pengembangan panduan. Wawancara juga diperlukan untuk mengetahui pendapat subjek mengenai panduan setelah dilakukan uji coba lapangan; (c) Angket : penggunaan angket berupa skala penilaian panduan konseling psikoreligius untuk remaja korban kekerasan dengan menggunakan skala untuk menilai dari 4 aspek utama dalam pengembangan panduan, antara lain: (1) aspek kegunaan panduan (utility), (2) aspek ketepatan panduan (accuracy), (3) aspek kesesuaian panduan (feasibility), dan (4) aspek kemudahan panduan (flexibility). Berdasarkan hasil penilaian oleh para ahli ini, kemudian dilakukan perbaikan dan analisis data tentang kelayakan panduan dari penilaian yang diberikan.

Analisis data dilakukan secara kuantitatif dan kualitatif. Data kuantitatif dianalisis dengan statistik deskriptif berupa pensekoran rata-rata, sedangkan data kualitatif berupa hasil wawancara, diskusi, komentar, saran, dan kritik dianalisis secara kualitatif. Data kuantitatif yang diperoleh dari uji ahli dianalisis dengan menggunakan pensekoran kemudian diverifikasi atau diuji kebenarannya. Data kualitatif diperoleh dari responden sasaran, responden pengguna, responden observer dan ahli.

\section{HASIL DAN PEMBAHASAN}

Hasil penyusunan panduan dapat dilihat dari penilaian ahli terhadap isi panduan. Aspek penilaian terhadap panduan meliputi: (1) aspek kegunaan panduan (utility), (2) aspek ketepatan panduan (accuracy), (3) aspek kesesuaian panduan (feasibility), dan (4) aspek kemudahan panduan (flexibility). Berdasarkan penilaian ahli menunjukkan bahwa modul/panduan dinilai baik dari sisi kegunaan, ketepatan, kesesuaian maupun kemudahan penggunaannya. Menurut ahli psikologi yang menilai panduan, sejumlah perbaikan dalam isi panduan perlu dilakukan misalnya terkait sapaan terhadap klien/konseli, kesesuaian pengantar dan penutup modul, pengaturan waktu tiap bagian secara lebih 
proporsional, ketepatan peraga/media dan redaksional tema tiap bagian. Adapun saran dari ahli keagamaan terutama berfokus pada penambahan isi dari aspek religious seperti pemilihan lafadz dzikir yang tepat saat relaksasi nafas, kemudian penambahan sejumlah hadits ataupun ayat-ayat Quran.

Panduan konseling psikoreligius yang telah direview oleh kedua ahli selanjutnya dilakukan uji coba untuk diimplementasikan dalam proses pemberian konseling pada remaja korban kekerasan. Peneliti menemukan 3 remaja yang mengalami kasus kekerasan dengan jenis kekerasan yang beragam. Ketiga remaja tersebut berusia 20 tahun yang dikategorikan sebagai remaja akhir. Adapun gambaran kasus dari ketiga responden tersebut adalah sebagai berikut: (a) Responden dengan inisial nama LU adalah seorang perempuan, mengalami trauma karena pelecehan seksual yang dilakukan sahabatnya sendiri yang juga seorang perempuan. Pelecehan yang menimpa responden adalah dicium di bagian bibir tanpa diketahui oleh LU karena ia ditutup matanya oleh sahabatnya. Akibat dari masalah itu LU mengalami banyak gejala Post Trauma syndrome dissoreder (PTSD) dan gejala stress traumatic yang dialaminya menunjukkan 9 dari 10 gejala traumatic; (b) Responden dengan inisial nama FH seorang perempuan, mengalami trauma karena kekerasan fisik yang dilakukan oleh ayahnya sendiri ketika FH masih berusia sekitar 10 tahun. Akan tetapi respon post Trauma syndrome dissoreder (PTSD) yang dirasakan masih cukup tinggi terbukti dengan banyaknya gejala stress yang dirasakan oleh $\mathrm{FH}$; (c) Responden dengan inisial nama WD seorang perempuan, mengalami trauma yang kompleks karena terdapat lima peristiwa yang dialaminya. Trauma yang sifatnya kekerasan ada tiga, yaitu; melihat kekerasan fisik ayahnya terhadap ibunya, menjadi korban bullying di pesantren hingga membuatnya melakukan tindakan self injury dan pelecehan seksual oleh mantan pacarnya (dipaksa mau dicium).

Penerapan konseling psikoreligius di lapangan pada ketiga responden tersebut, sesuai dengan podoman yang telah divalidasi oleh kedua pakar ahli maka ketiga responden menunjukkan penurunan gejala trauma dan stress yang berlebih. Setelah mengikuti 4 kali sesi konseling, para responden menampakkan adanya beberapa perubahan yaitu : peningkatan dalam kemampuan kontrol emosi khususnya emosi negative yang merupakan efek dari trauma, kemampuan dalam mengidentifikasi isi pikiran yang mengganggu dan merubah dengan isi pikiran yang lebih realistis dan positif serta adanya perubahan dalam penggunaan cara coping dengan lebih banyak memilih bentuk coping religious. Selain itu mereka juga mampu menemukan hikmah serta belajar dari permasalahan trauma yang pernah mereka alami. Adanya peningkatan-peningkatan tersebut menjadikan para responden lebih mampu dalam menanggulangi efek trauma yang dirasakannya sehingga meningkat pula rasa aman yang mereka miliki. Ketika rasa aman telah kembali dapat mereka miliki, mereka selanjutnya mampu menuliskan harapan-harapan untuk diri dan masa depan mereka dengan cara yang berbeda dan lebih baik daripada sebelum mengikuti konseling religious.

Hasil penelitian ini sejalan dengan temuan penelitian Harris (dalam Ross, Kennedy \& Macnab: 2015) tentang penggunaan pendekatan religi spiritualitas untuk mengatasi trauma pada veteran yang pernah mengalami paparan trauma kekerasan. Para responden setelah 8 sesi menunjukkan adanya peningkatan dalam tujuan-tujuan spiritual mereka serta adanya rencana lanjutan untuk mengembangkan spiritualitas mereka. Selain itu mereka juga menunjukkan penurunan simtom PTSD.

Hasil penelitian ini juga mendukung hasil review Hefti (2011) terhadap sejumlah hasil penelitian penting tentang dampak positif religi dan spiritual terhadap kesehatan mental seperti lebih sehat secara fisik, lebih mampu melakukan penyesuaian secara psikologis serta tingkat yang lebih rendah dalam problem perilaku sosial. Religi dan spiritual juga membantu individu untuk memiliki harapan serta dorongan untuk mengalami pertumbuhan diri secara positif.

Meichenbaum seorang ahli terapi kognitif menegaskan pentingnya spiritualitas dalam proses penyembuhan termasuk untuk kasus trauma (melissainstitude, 2017). Kolaborasi spiritual dalam konseling dan psikoterapi menjadi hal yang penting karena banyaknya penelitian yang membuktikan peran keyakinan dan perilaku spiritual dalam kesehatan mental dan pengaruhnya dalam proses psikoterapi (Daniels \& Fitzpatrick, 2013; Plumb, 2011).

\section{SIMPULAN DAN SARAN}

Hasil penelitian ini menunjukkan bahwa proses pemberian bantuan kepada remaja korban 
kekerasan dapat dilakukan dengan menggunakan panduan konseling psikoreligius yang telah disusun oleh peneliti. Panduan tersebut dimodifikasi dari modul untuk penanganan trauma untuk remaja yang disusun oleh Cohen, Mannarino \& Deblinger (2006) yang berbasis CBT namun dalam penelitian ini dipadukan pendekatan religious.

Implementasi panduan terhadap responden remaja yang mengalami kekerasan menunjukkan hasil adanya penurunan gejalagejala pasca trauma yang ditunjukkan oleh peningkatan dalam kemampuan kontrol emosi khususnya emosi negative yang merupakan efek dari trauma, kemampuan dalam mengidentifikasi isi pikiran yang mengganggu dan merubah

\section{DAFTAR RUJUKAN}

Appleyard, K. Yang, C. \& Runyan, D.K. 2010. Delineating the maladaptive pathways of child maltreatment: the mediated roles of self-perception and social support. Development and Psychopathology. 22, 337-352

Carr, A. 2006. The handbook of child and adolescent clinical psychology, a contextual approach. Second edition. Routledge. New York

Chen, Y. Y. 2005. Written emotional expression and religion: effects on PTSD symtoms. International Journal Psychiatry in Medicine. Vol 35(3) 273286

Cohen, J.A. Hendricks, A. Mannarino, P. \& Deblinger, E. 2006. Dealing with trauma: a TF-CBT workbook for teens.

Daniels, C. \& Fitzpatrick, M. 2013. Integrating Spirituality into Counselling and Psychotherapy: Theoretical dan Clinical Perspective. Canadian Journal and Psychotherapy. Vol.47. No. 3. 315341

Ehlers, A. \& Clarke, D. M. 2000. A cognitive model of posttraumatic stress disorder. Behavior Research and Therapy, 38, 319-345

Emmons, R.2005. Emotions and religion. In R.F. Paloutzian \& C.L. Park (Eds.), Handbook of psychology of religion and spirituality. (pp. 231-252). New York: Guilford Press dengan isi pikiran yang lebih realistis dan positif serta adanya perubahan dalam penggunaan cara coping dengan lebih banyak memilih bentuk coping religious. Selain itu mereka juga mampu menemukan hikmah serta belajar dari permasalahan trauma yang pernah mereka alami.

Saran terkait dengan penggunaan hasil penelitian ini adalah : 1) perlunya pelatihan bagi konselor sebelum penggunaan panduan; 2) perlunya penyesuaian implementasi panduan terhadap kondisi klien baik dari sisi keparahan trauma, jumlah sesi maupun usia; 3) perlunya memastikan kemampuan stabilisasi klien telah diperoleh sebelum sesi bercerita agar dapat mampu menghindari abreaksi yang tidak terkendal

Geldard, K. Geldrad, D. \& Foo. 2016. Konseling Anak-anak; Panduan Praktis. Edisi keempat. Penerbit Indeks. Jakarta

Hefti, R. 2011. Integrating religion and spirituality into mental health care, psychiatry and psychotherapy. Religions. 2, 611-627; doi: 10.3390

Johnson, R.M., Kotch, J.B., Catellier, D.J., Winsor, J.R., Dufort, V., Hunter, W. et al. 2002. Adverse behavioral and emotional outcomes from child abuse and witnessed violence. Child Maltreatment. 7, 179-186

Komisi Perlindungan Anak Indonesia. 07 Desember 2016. Selama 2016, KPAI Catat 1000 Kasus Kekerasan pada Anak (Online). (http://www.kpai.go.id/berita/8194/), diakses 12 September 2017

MacMillan, R. 2001. Violence and the life course: the consequences of victimitation for personal and social development. Annual Review of Sociology. 27: 1-22

Meichenbaum, D. tanpa tahun. Trauma, Spirituality and Recovery: Toward A Spiritually-Integrated

Psychotherapy.www.melissainstitue.or $\mathrm{g}$

Maslihah, S. 2013. Play therapy dalam identifikasi kasus kekerasan seksual terhadap anak. Jurnal Penelitian Psikologi. Vol. 04. No. 01, 21-34 
Plumb, A.M. 2011. Spirituality and counselling: are counsellors prepared to integrate religion and spirituality into therapeutic work with clients. Canadian Journal and Psychotherapy. Vol.45. No. 1. 1-16

Puspitawati, H. Djamaludin, M.D, \& Nursanti, H. 2011. Kekerasan, kondisi keluarga, dan kesejahteraan keluarga pada anak korban kekerasan. Jurnal Ilmu Keluarga dan Konsumen. Agustus, Vol. 4. No. 2. 130-138

Richards, P.S, \& Bergin, A.E, 2006. A spiritual strategy for counseling and psychotherapy. Second edition. American Psychologist Association. Washington D.C,U.S

Ross, J.J., Kennedy, G., \& Macnab, F. 2015. The effectiveness of spiritual/religious interventions in psychotherapy and counseling; a review of the recent literature. PAFCA, Melbourne
Shapiro, F. 2012. Getting past your past: take control of your life with self-help techniques from EMDR therapy. MacMillan, USA

Sholichatun, Y. 2015. Karakteristik korban, pelaku dan bentuk kekerasan pada anak di Kabupaten Malang antara tahun 2012-2015. Penelitian Fakultas Psikologi UIN Malang, Tidak Diterbitkan

Subandi. 2002. Latihan meditasi untuk Psikoterapi. Dalam Psikoterapi pendekatan konvensional dan kontemporer. Unit Publikasi Fakultas Psikologi UGM Yogyakarta

Watts, F. 2007. Emotion regulation and religion. In J. J. Gross (Ed.), Handbook of emotion regulation. (pp. 504-520). New York: Guilford Press. 